\title{
Socio-Cultural Adjustment and Job Performance Among Expatriates: A Critical Overview
}

\author{
Md. Sayed Uddin \\ Sociology and Social Anthropology, Faculty of Humanities, Arts \& Heritage, \\ Universiti Malaysia Sabah, Jalan UMS, 88400, Kota Kinabalu, Sabah, Malaysia \\ E-mail: sayed@ums.edu.my
}

Rosazman Hussin

Borneo Institute for Indigenous Studies (BorIIS)

Universiti Malaysia Sabah, Jalan UMS, 88400, Kota Kinabalu, Sabah, Malaysia

E-mail: azzs@ums.edu.my

Badariah Ab Rahman

Industrial Relations Programme, Faculty of Humanities, Arts \& Heritage, Universiti Malaysia Sabah, Jalan UMS, 88400, Kota Kinabalu, Sabah, Malaysia E-mail: badariah_abrahman@ums.edu.my

Received: Nov. 5, 2019 Accepted: Dec. 13, 2019 Online published: Dec. 16, 2019 doi:10.5296/ijhrs.v10i1.16046ＵRL: https://doi.org/10.5296/ijhrs.v10i1.16046

\begin{abstract}
The significant aspect of the migration process is the adjustment to the socio-cultural as well as work conditions of the host country. Expatriates' by and large, come from quite different socio-cultural backgrounds and different work conditions. They are acquainted with different norms and used to different work ethics which have shaped their performance and relations with persons at work. They have to work in a new situation with new personnel and have to adjust to the entire new socio-cultural and working scenarios. It is interesting yet a problematic phenomenon to study their social life, their adjustment to the new socio-cultural milieu, work environment and adoption to innovation in professional arenas. Thus, if the expatriates in one hand can adjust to the situation, they may perform their job well and
\end{abstract}


complete their assignment; otherwise, their stay in the host country will adversely be affected. Thus, socio-cultural adjustment along with innovation adoption is an important phenomenon that affects expatriates' stay in the host country, their performance at work and relation with co-workers. The research will carry out using the secondary sources; an overview of existing literatures. It will help to rectify the factors associated to suitable candidates for the organizations/institutions to hire the competent and multiskilled expatriates to host country.

Keywords: socio-cultural adjustment, job performance, expatriates

\section{Introduction}

Expatriates are professional skilled migrants who usually come from quite different socio-cultural backgrounds and different work conditions. They are acquainted with different norms and used to different work ethics which have shaped their performance and relations with persons at work. They have to work in a new situation with new personnel and have to adjust to the entire new socio-cultural and working scenario. If they cope with the problems which they face and adjust to the situation, they may perform their job well and complete their assignment; otherwise their stay in the host country will adversely be affected. Thus, adjustment is an important phenomenon that affects expatriates stay in the host country, their performance at work and relation with colleagues. According to Hechanova (2003: 215), adjustment affects other work-related outcomes such as strain, job satisfaction, organizational commitment, performance, and turnover intent. Therefore, this paper focuses on the relationships between expatriates adjustment and performance based on previous literature on general, work, and interaction adjustment and outcome (job performance).

The concept of adjustment is developed by Black (1988) who used it in both subjective and objective ways and applied it to the study of overseas expatriates. According to him, adjustment subjectively "is the degree of comfort the incumbent feels in the new role and the degree to which he or she feels adjusted to the role requirements. Objectively, it is the degree to which a person has mastered the role requirements and is able to demonstrate that adjustment via his or her performance" (Black, 1988: 278). Black refines the concept in his further researches in collaboration with others (e.g. Black \& Gregersen, 1991a, 1991b; Black $\&$ Stephens, 1989). He modifies his concept in his study of expatriate adjustment based on the works of Nicholson (1984) and Dawis and Lofquist (1984), and points out the differences between domestic employees and expatriates. In this context, he explains adjustment "as the expatriate's psychological comfort with respect to the environmental demands." He considers three dimensions of adjustment: work adjustment, general adjustment and interaction adjustment. Showail (2007) explains that work adjustment relates to the psychological comfort with respect to new job roles while general adjustment focuses on psychological comfort with non job-related aspects of the new job (living conditions). Interaction adjustment considers the ability of the foreign workers to interact or have relationships with the natives of the country in which they are working (Showail, 2007: 23).

As mentioned earlier discussion, this study attempts to explore related previous literature on three facets of socio-cultural adjustment in relation with job performance. First, it examines the general adjustment of the workers to non-work factors in the host country. It relates, as 
Showail (2007) and Torbiorn (1982) explains, the general conditions of living such as food, clothing, entertainment and weather. In this context the study assesses how comfortable the workers are with these factors and how much they adapt to the locally available materials. This adjustment is important because it has been observed in various studies (e.g. Takeuchi, Yun \& Telsluk, 2002) that if the expatriates are unable to tolerate locally available food their performance would not be up to the mark.

Work adjustment is explained "as psychological comfort felt with respect to the job tasks of the foreign assignment" (Black et al., 1991). According to Black et al. (1991) it relates to 'role novelty' that enables us to evaluate how different the present job is from the previous job of expatriates. It, in fact, indicates what expectations have been attached to the nature of the job. Work adjustment is the adjustment to work conditions including their responsibilities, abilities, skills, expectations, differences of job tasks from previous and present, etc. According to Showail (2007: 26):

"Work adjustment is the psychological comfort with respect to the foreign assignment as they relate to differing work values, expectations, and standards."

Work adjustment assessed by expatriates comfort with the nature of the work including work values, expectations and standards. The fact is that national culture plays an important role in shaping the work environment (Hofstede, 1980). Generally, the recruited organization or companies adapt to the national cultural norms. Thus, it is necessary to get acquainted with those norms and practice them in concrete situations. Showail (2007: 28) observes that "cultural differences between the culture of the country in which the foreign worker is employed and the culture of the foreign worker's home country will have impact on work adjustment, where things in the company are done in compliance with national cultural norms".

Interaction adjustment indicates the psychological comfort with respect to interaction with the people in the host country (Black et al.,1991). Interaction adjustment is the expatraite psychological comfort with respect to interactions with the host country nationals (Showail, 2007; Hechanova, 2003; Black et al., 1991). In general, if expatriates have close relationship with local people they understand the problems and position of each other, get better acquainted with cultural norms, living and working standard of the host society and manifest them in their action.

\section{Method}

This research paper is based on data from secondary sources. The researchers have used online databases, books, journals, reports, electronic sources and articles from numerous sources to collect the findings of previous literature in relation to expatriate's socio-cultural adjustment and job performances. The search procedures of sources include themes related to general, work and interaction adjustment related to the expatriate job outcomes. 


\section{A Critical Overview on Socio-Cultural Adjustment and Job Performance}

According to Ward and Kennedy (1999), culture and ethnic similarity are associated with better socio-cultural adjustment. In their study, they observe that while Malaysian students in Singapore do not have any socio-cultural adaptation problem, their Singaporean cohorts in New Zealand are not immune from such difficulties. Similarly, compared to Anglo Europeans in Singapore, Chinese sojourners encounter less adaptation problems over there. However, when it comes to economic prosperity of a nation, Ward and Kennedy (1999) argue that such adaptation is easier in modern and developed societies; this is evidenced by the fact that multi-national aid employees working in Nepal face harsher realities than those in Singapore. Their study presents significance as it addresses the cross-cultural adjustment from both psychological and socio-cultural standpoints.

The most important literature found on the issue of expatriate socio-cultural adjustment and job performance are studies Black et al. (1991) model on three dimensions namely, general or non-work, work and interaction adjustments. The Black et al. model is significant as it is applied to investigate expatriates' socio-cultural adjustment in host country. The extant literature offers a plethora of studies in this regard (Bright, 2008; Showail, 2007; Hechanova et al.,2003; Reynolds, 2010; Ward \& Kannedy, 1999; Selmer et al.,2007; Fish, 2005). Black et al. contend that the degree of socio-cultural adjustment is contingent upon cultural proximity (or lack of it) of the two countries. This apart, cultural novelty, according to them, exerts more influence on aspects vis-à-vis interaction and general adjustment. Their seminal study highlights a few major attributes of socio-cultural adjustment such as pre-departure training, previous international experience, individual self efficacy, relational and perceptual skills, characteristics of the expatriate job (i.e., role conflict, discretion and clarity), social support, logistical help, organizational socialization process, family and spouse adjustment. The key role played by these factors also finds its resonance in other subsequent studies (Selmer, 1999; Showail, 2007).

Instead of expatriate socio-cultural adjustment, Showail (2007) coins the term 'foreign workers' socio-cultural adjustment, as he reasons that there are some differences between expatriates and foreign workers in terms of their professionalism, working contract, awareness of job responsibilities, etc. The study is conducted in Saudi Arabia through a web based survey on 150 foreign workers investigated on their general or non-work, work and interaction adjustment in relation to their job performance. The study's finding that general adjustment (such as food) is important for workers' productivity is validated by previous research as well (Takeuchi, Yun \& Tesluk, 2002). In addition, according to him, high work adjustment, being the most significant dimension for foreign workers, tends to translate into their superior performance. In this regard, he observes that organizational support and justice meted out to them as perceived by workers are positively correlated with their job performance.

Hofstede (1980) conducts a seminal study on national culture, where it is regarded as an antecedent to work adjustment. However, not only with job related issues, cultural differences also influence in interaction adjustment with host country nationals (Showail, 2007; Van 
Vianen et al., 2004). To Showail, the nature of relationship between foreign workers and host nationals also exerts an impact on job performance. However, his study is confined in its scope in the sense as it leaves the aspects of foreign language skills and prior experience influencing work adjustment outside its purview (Reynols, 2010; Takeuchi et al.,2002).

Bright's (2008) study reveals that having friends from the host countries is a significant feature to adjust in a new socio-cultural environment. His study seems to be very significant and relevant as other researchers like Cooke (2003), Hechanova et al. (2003), Mayerhofer and Scullion (2002), McGinley (2007), Sargeant (2002), Selmer (2001), Sims and Schraeder (2004) also found a similar observation of having local friends in host country as a positive way of making socio-cultural adjustment. Socio-demographic factors like age, marital status, educational level, etc. are also important factors in adjusting in a host country. Bright (2008) asserts that there are negative correlations between language skills, previous experience with that of socio-cultural adjustment. In this context, the findings contradict many previous studies, which have found that language skills and previous experience are most influential factors on three facets of socio-cultural adjustment (Andreason, 2003; Bhaskar Shrinivas et al.,2004; Bird, Black \& Stephens, 1989; Fenner, 2005; Garson, 2005; Hechanova et al.,2003; Johnson et al.,2006; Mendenhall \& Oddou, 1985; Rushing \& Kleiner, 2003; Sargent, 2002; Selmer, 2001; Selmer, 2005; Shaffer et al.,1999; Shim, 2001; Von Glinow et al.,2004).

Reynold (2010) suggests that age, educational level, amount of satisfaction with previous work experiences, length of employment in current job, employing institution and location of the city are important factors in socio-cultural adjustment. His study also finds that age and educational level are the influential factors in the degree of cultural adjustment. Previous studies done by Hechanova et al. (2003) and Stahl and Caligiuri (2005) similarly reveal that age is the most influential factor for socio-cultural adjustment. Reynold correlates the factors of overseas work experiences, foreign language ability and culture novelty as important correlates for adjustment in a work-place. His study shows that cultural novelty is the most influential factor for cultural adjustment although Black et al. (1991), Bhaskar-Shrinivas et al. (2005), Hechanova et al. (2003), Shaffer et al. (1999), Takeuchi et al. (2002) do not find any relationship with cultural novelty and the three facets like non-work, work and interaction for adjustment. Reynold's (2010) findings however indicate that foreign language ability and previous overseas work experiences have negative relation with the three facets of socio cultural adjustment. On the contrary, studies by Bhaskar-Shrinivas et al. (2005), Hechanova et al. (2003), Shaffer et al. (1999), and Takeuchi et al. (2002) show that foreign language ability is the most influential factor in interaction and work adjustment. In addition, the studies of Bhaskar-Shrinivas et al. (2005), Black (1988), Hechanova et al. (2003), Shaffer et al. (1999) find that previous overseas work experience is more significant in interaction adjustment in a particular working situation.

Waxin (2004) describes that interaction adjustment is more or less difficult for the expatriates from the country of origin. It indicates that cultural similarity or, short cultural distance often help people to adjust in a new situation (Gudykunst \& Hammer, 1984). Waxin's (2004) study is important in regard to studying the expatriates' interaction relating it to adjustment. In the methodological part, Waxin surveys 224 expatriates from different cultural backgrounds 
namely, French, German, Korean and Scandinavian whose working experiences in India found that the culture of origin has direct effect on interaction adjustment. Her study reveals that the wider the cultural distance, the lesser the interactional adjustment. For example, the Korean expatriates are found to have a lesser degree of interactional adjustment than the French.

Previous studies also found cultural differences between origin and host country in connection to interaction adjustment (Black et al.,1991; Church, 1982; Mendenhall \& Oddou, 1985; Furnham \& Bocher, 1982; Parker \& McEvoy, 1993; Gregersen \& Stroh, 1997). Waxin (2004) notes that in the case of wider cultural distance between origin and host countries, the supervisory and partner support are often very influential. This study however, has limitation in investigating cultural distance in connection with one dimension which is regarded as interaction adjustment. Selmer et al. have found that cultural distance are positively related to three dimensions (non-work, work, interaction) of socio-cultural adjustment.

According to Andreason (2003), ineffective performance and often, premature return of expatriates from foreign assignments is the result of inability to adjust in a foreign environment. He identifies three dimensions of adjustment: adjustment to work, adjustment to interactions with people in the foreign country and general adjustment to the culture and living conditions, which are crucial for studying socio-cultural adjustment. He notes that in foreign assignments, the candidate's selection and recruitment process should give priority to two factors. These are previous international assignment experience and host country language experience. To him, previous experience, especially same country experience reduces cultural shock which becomes very much helpful on interactions and adjustment. Many previous studies also gave importance to previous experience (Black et al.,1991; Shaffer et al.,1999; Bell \& Harrison, 1996; Selmer, 2002). Black et al. (1991) identify it as an important factor which usually facilitates work and general adjustment. Andreason (2003) states that language skill is more important on three facets of socio-cultural adjustment and previous studies also support that the ability to speak in host country language is more helpful for socio-cultural adjustment (Price Waterhouse, 1997; Nicholson \& Imaizumi, 1993).

Fish (2005) proposes eight cross-cultural interventions to assist the personal well-being (phycho-culture) and cultural interaction (socio-cultural) of international assignments. His study was conducted on Australian expatriates in Southeast Asia. Fish (2005) notes that both pre-departure and in-country interventions including quality of life awareness, host business and cultural awareness, family impact awareness, staff and business colleague awareness, home country networks, cultural reinforcement and support, cultural inclusion and host language skill are important to adjust in any new situation. He suggests that dealing with these specific adjustment interventions will decrease the potential for anxiety, tension, stress or illness. Guillen (2001) also suggest that foreign language skill is very important for adjustment.

Selmer et al. (2007) note that cultural dissimilarity between host and home culture increases adjustment difficulties. This study is important where Selmer et al. have described a comparable adjustment scenario on psychological and socio-cultural adjustment perspectives. 
Their research methods are notable. Among the two countries, the USA was chosen as one of the two countries in the sample by using a two-flow sample: one, the US expatriates working in Germany and German expatriates coming into the USA. However, both socio-culturally and psychologically, Selmer et al.'s (2007) study finds that the German expatriates in the USA are better adjusted than the Americans in Germany. For instance, result indicates that the American business expatriates in Germany had a lower extent of adjustment than the Germans in America in general, interaction adjustment, work adjustment, and psychological adjustment. For that reason Selmer et. al. (2007) suggest that business firms should provide cross cultural training to prepare their expatriates for future assignment.

Hechanova (2003) highlights the most influential factors which facilitate easier adjustment in an assignment. He finds that self-efficacy, frequency of interaction with host nationals, and family support predicted all three types of adjustments. Further, his study also describes adjustment outcomes of three dimensions of sociocultural adjustments (general adjustment, work adjustment and interaction adjustment). His study finds that better interpersonal skills are associated with greater adjustment to general environment. Greater cultural novelty (cultural difference) is associated with less interactional adjustment. Role conflict, ambiguity, and discretion are also strong predictors of work adjustment. According to Hechanova (2003: 215), adjustment affects other work-related outcomes such as strain, job satisfaction, organizational commitment, performance, and turnover intent. In the methodological part, his study uses a structural equation model (SEM) which illustrates causal relationship and outcomes such as job strain, job satisfaction, organizational citizenship, intent to turn over, and job performance as a good fit with data. Studies by Dawis and Lofquist (1984), Nicholson (1984) Naumann, (1993) also investigated expatriates' adjustment and outcomes .

\section{Conclusion}

It is important to understand how serious expatriates are about work, how they adopt the norms and standards at work and fulfill the expectations of management. Most influential factors which facilitate easier adjustment in an overseas assignment are cultural similarity or short cultural distance; foreign language skills; previous overseas experience; having local friends in host country; family support or spouse adjustment in foreign country; and length of employment in current job. Moreover, the place where they work should have proper instruments and facilities necessary for them to perform the specified tasks. These, of course, affect the efficiency of the expatriates. Besides, working hours, social security, access to gain resources, relation with colleague, leisure time and religious activities are some of the factors that provide encouragement to the expatriates and should be assessed to know their roles in the efficiency of the expatriates.

\section{Acknowledgement}

This research was supported by a grant from Pusat Pengurusan Penyelidikan Dan Inovasi (PPPI), Universiti Malaysia Sabah, under the project "expatriates' socio-cultural adjustments and job performances: A case study of Sabah, Malaysia" (SLB0190-2019). 


\section{References}

Andreason, A. W. (2003). Expatriate adjustment to foreign assignments. Journal of Commerce \& Management, 1(13), 42-61. https://doi.org/10.1108/eb047459

Bell, M. P., \& Harrison, D. A. (1996). Using intra-national diversity for international assignments: A model of bicultural competence and expatriate adjustment. Human Resource Management Review, 6(1), 47-74. https://doi.org/10.1016/S1053-4822(96)90004-2

Bhaskar-Shrinivas, P., Harrison, D. A., Shaffer, M. A., \& Luk, D. M. (2005). Input-based and time-based models of international adjustment: Meta-analytic evidence and theoretical extensions. Academy of Management Journal, 48(2), 257-281. https://doi.org/10.5465/amj.2005.16928400

Bhaskar-Shrinivas, P., Harrison, D. A., Shaffer, M. A., \& Luk, D. M. (2004). What have we learned about expatriate adjustment? Answers accumulated from 23 years of research. Academy of Management Proceedings, A1-A6. Retrieved October 8, 2006, from EBSCOhost database. https://doi.org/10.5465/ambpp.2004.13863144

Black et al. (1991). Toward a comprehensive model of international adjustment: An integration of multiple theoretical perspectives. Academy of management review, 16(2), 291-317. https://doi.org/10.5465/amr.1991.4278938

Black, J. S. (1988). Work role transitions: A study of American expatriate managers in Japan. Journal of International Business 277-294. https://doi.org/10.1057/palgrave.jibs.8490383

Black, J. S., \& Gregersen, H. (1991). Antecedents to cross-cultural adjustment for expatriates in Pacific Rim assignments. Human Relations, 44, 497-515. https://doi.org/10.1177/001872679104400505

Black, J. S., \& Gregersen, H. (1991). The other half of the picture: Antecedents of spouse cross-cultural adjustment. Journal of International Business Studies, 22(3), 461-477. https://doi.org/10.1057/palgrave.jibs.8490311

Black, J. S., \& Stephens, G. K. (1989). The influence of the spouse on American expatriate adjustment and intent to stay in Pacific Rim overseas assignments. Journal of Management, 15(4), 16. https://doi.org/10.1177/014920638901500403

Bright, C. C. (2008). Investigating the relationship between expatriate adjustment, marital status, and related attributes. University of Phoenix.

Chung, K., \& Seok, H. (2000). Cultural and social adjustment: Migrant workers in Korea and local workers in overseas Korean firms. Asian and Pacific Migration Journal, 9(3), 287-309. https://doi.org/10.1177/011719680000900304

Church, A. (1982). Sojourner adjustment. Psychological Bulletin, 91, 540-572. https://doi.org/10.1037/0033-2909.91.3.540

Cooke, L. F. (2003). Female expatriates: How to maximise their success. People Management, 
$11(9), 48-49$.

Dawis, R. V., \& Lofquist, L. H. (1984). A psychological theory of work adjustment. Minneapolis, MN: University of Minnesota Press.

Fenner, C. R. (2005). Turnover activities and international adjustment of defense administrators. California, U.S.A. Touro University International. Retrieved from ProQuest Dissertations Publishing, (3179450).

Fish, A. (2005). Assisting cross-border manager adjustment: Psycho-cultural and socio-cultural interventions. Personnel Review, 34(2), 225-245. https://doi.org/10.1108/00483480510579448

Garson, B. (2005). Teaching abroad: A cross-cultural journey. Journal of Education for Business, 80(6), 322-326. https://doi.org/10.3200/JOEB.80.6.322-326

Gregersen, H. B., \& Stroh, L. (1997). Coming home to the Arctic cold: Antecedents to Finnish expatriates and spouse repatriation. Personnel Psychology, 50(3), 635-654. https://doi.org/10.1111/j.1744-6570.1997.tb00708.x

Gudykunst, W. R., \& Hammer, M. R. (1984). Dimensions of intercultural effectiveness: culture specific of culture general? International Journal of Intercultural Relations, 8, 1-10. https://doi.org/10.1016/0147-1767(84)90003-8

Guillen, M. (2001), "What is the best global strategy for the internet?", Wharton School, University of Pennsylvania, Philadelphia, PA.

Hadiz, V., \& Beeson, M. (1998). Labour and the politics of structural adjustment in Australia and Indonesia. Journal of Contemporary Asia, 28(3), 291-309. https://doi.org/10.1080/00472339880000171

Hechanova, R. (2003). Antecedents and consequences of employees' adjustment to overseas assignment: A meta-analytic review. Applied psychology: an International Review, 52(2), 213-236. https://doi.org/10.1111/1464-0597.00132

Hechanova, R., Beehr, T. A., \& Christiansen, N. D. (2003). Antecedents and consequences of employees' adjustment to overseas assignment: A meta-analytic review. Applied Psychology: An International Review, 52(2), 213-236. https://doi.org/10.1111/1464-0597.00132

Hofstede, G. (1980). Culture's consequences, international differences in work related values. Beverly Hills, Calif.: Sage Publications.

Johnson et al. (2006). Cross-cultural competence in international business: Toward a definition and a model. Journal of International Business Studies, 37(4), 525-543. https://doi.org/10.1057/palgrave.jibs.8400205

Mayrhofer, W., \& Scullion, H. (2002). Female expatriates in international business: Empirical evidence from the German clothing industry. International Journal of Human Resource Management, 13, 815-836. https://doi.org/10.1080/09585190210125958 


\section{Ml Macrothink}

International Journal of Human Resource Studies ISSN 2162-3058 2020, Vol. 10, No. 1

McGinley, J. E. (2007). Expatriate adjustment: Resources, responses, and outcomes. Northcentral University. Retrieved February 27, 2013, from ProQuest Dissertations and Theses database. (AAT 3269820)

Mendenhall, M., \& Oddou, G. (1985). The dimensions of expatriate acculturation. Academy of Management Review, 10(3), 39-47. https://doi.org/10.5465/amr.1985.4277340

Naumann, E. (1993). Antecedents and consequence of satisfaction and commitment among expatriate managers. Group and Organization Management, 18(2), 153-187. https://doi.org/10.1177/1059601193182003

Nicholson, N. (1984). A theory of work role transitions. Administrative science Quarterly, 29, 172-191. https://doi.org/10.2307/2393172

Nicholson, N., \& Imaizumi, A. (1993). The adjustment of Japanese expatriates living and working in Britain. British Journal of Management, 4, 119-34. https://doi.org/10.1111/j.1467-8551.1993.tb00052.x

Parker, B., \& Mcevoy, G. M. (1993). Initial examination of a model of intercultural adjustment. International Journal of Intercultural Relations, 17, 355-379. https://doi.org/10.1016/0147-1767(93)90039-B

Price Waterhouse. (1997-1998). International assignments: European policy and practice. 1997/1998, Europe. Berlin: Price Waterhouse.

Reynolds, A. A. (2010). The academic expatriate in the united arab emirates: a new Lens through which to view expatriate sociocultural Adjustment. Retrieved from ProQuest Dissertations Publishing, 3418157.

Rushing, K., \& Kleiner, B. H. (2003). New developments in executive relocation Practices. Management Research News, 26, 12-19. https://doi.org/10.1108/01409170310783745

Sargent, T. (2002). Boundaryless careers in the age of globalization: Cross-cultural adjustment of westerners in Japan in terms of motivation to initiate sojourn. University of Sarasota. Retrived from ProQuest Dissertations Publishing, 3058730.

Selmer, J. (1999). Effects of coping strategies on sociocultural and psychological adjustments of western expatriate managers in the PRC. Journal of World Business, 1(34), 41-51. https://doi.org/10.1016/S1090-9516(99)00006-1

Selmer, J. (2001). Psychological barriers to adjustment and how they affect coping strategies: Western business expatriates in China. International Journal of Human Resource Management, 2(12), 151-165. https://doi.org/10.1080/09585190122767

Selmer, J. (2002). Practice makes perfect? International experience and expatriate adjustment. Management International Review, 1(42), 71-88.

Selmer, J. (2004). Psychological barriers to adjustment of Western business expatriates in China: Newcomers versus long stayers. International Journal of Human Resource Management, 15(4/5), 794-813. https://doi.org/10.1080/0958519042000192951 
Selmer, J. (2005). Is bigger better? Size of the location and expatriate adjustment in China. International Journal of Human Resource Management, 7(16), 1228-1242. https://doi.org/10.1080/09585190500144178

Selmer, J. et al. (2007). Cultural distance asymmetry in expatriate adjustment. Cross-cultural management: an International Journal, 14(2), 150-160. https://doi.org/10.1108/13527600710745750

Shaffer et al. (1999). Dimensions, determinants, and differences in the expatriate adjustment process. Journal of International Business Studies, 30(3), 557-581. https://doi.org/10.1057/palgrave.jibs.8490083

Shim, I. (2001). Factors that facilitate or limit expatriates' adapting and adjusting to another country. Texas A \& M University. ProQuest Dissertations Publishing, 3011800.

Showail, S. J. (2007). Foreign workers in Saudi Arabia and their sources of adjustment: The role of supervisor and spouse support. Washington University in St. Louis. Retrieved from ProQuest Dissertations Publishing, 3268087.

Sims, R., \& Schraeder, M. (2004). An examination of salient factors affecting expatriate culture shock. Journal of Business and Management, 1(10), 73-87.

Sonderegger, R., Barrett, R., Paula, M. (2004). Patterns of cultural adjustment among young migrants to Australia. Journal of Child and Family Studies, 13(3), 341-356. https://doi.org/10.1023/B:JCFS.0000022039.00578.51

Stahl, G. K., \& Caligiuri, P. (2005). The effectiveness of expatriate coping strategies: the moderating role of cultural distance, position level, and time on the international assignment. Journal of Applied Psychology, 90(4), 603-615. https://doi.org/10.1037/0021-9010.90.4.603

Takeuchi, R., Yun, S. \& Tesluk, P. (2002). An examination of crossover and spillover effects of spousal and expatriate cross-cultural adjustment on expatriate outcomes. Journal of Applied Psychology, 87 (4), 655. https://doi.org/10.1037/0021-9010.87.4.655

Takeuchi, R., Yun, S., \& Russell, J. E. A. (2002). Antecedents and consequences of the perceived adjustment of Japanese expatriates in the USA. International Journal of Human Resource Management, 13(8), 1224-1244. https://doi.org/10.1080/09585190210149493

Torbiorn, I. (1982). Living abroad: Personal adjustment and personal policy in the overseas setting. New York: Wiley.

Van der Bank, M., \& Rothmann, S. (2006). Correlates of expatriates' cross-cultural adjustment. Management Dynamics, 15(4), 29-39.

Van Oudenhoven, J. P., Mol, S., \& Van der Zee, K. I. (2003). Study of the adjustment of Western expatriates in Taiwan ROC with the multicultural personality questionnaire. Asian Journal of Social Psychology, 2(6), 159-171. https://doi.org/10.1111/1467-839X.t01-1-00018

Van Vianen, A. E., De Pater, I. E., Kristof-Brown, A. L., \& Johnson, E. C. (2004). Fitting in: Surface-and deep-level cultural differences and expatriates' adjustment. Academy of 


\section{Macrothink}

International Journal of Human Resource Studies

ISSN 2162-3058 2020, Vol. 10, No. 1

Management Journal, 47(5), 697-709. https://doi.org/10.5465/20159612

Von Glinow et al. (2004). Can we talk, and should we? Managing emotional conflict in multicultural teams. Academy of Management Review, 29(4), 578-592. https://doi.org/10.5465/amr.2004.14497611

Ward, C., \& Kennedy, A. (1996). Crossing cultures: The relationship between psychological and sociocultural dimensions of cross-cultural adjustment. In J. Pandey, D. Sinha, \& D. P. S. Bhawuk (Eds.), Asians contributions to cross-cultural psychology, 289-306. New Delhi, India: Sage.

Ward, C., \& Kennedy, A. (1999). The measurement of socio-cultural adaptation. Int. J. Intercultural Rel., 23(4), 659-677. https://doi.org/10.1016/S0147-1767(99)00014-0

Ward, C., \& Kennedy, A. (2001). Coping with cross-cultural transition. Journal of Cross-Cultural Psychology, 32(5), 636-642. https://doi.org/10.1177/0022022101032005007

Waxin Marie France (2004). Expatriates' interaction adjustment: the direct and moderator effects of culture of origin. International Journal if Intercultural Relations, 28, 61-79. https://doi.org/10.1016/j.ijintrel.2003.12.006

\section{Copyright Disclaimer}

Copyright for this article is retained by the author(s), with first publication rights granted to the journal.

This is an open-access article distributed under the terms and conditions of the Creative Commons Attribution license (http://creativecommons.org/licenses/by/4.0/). 